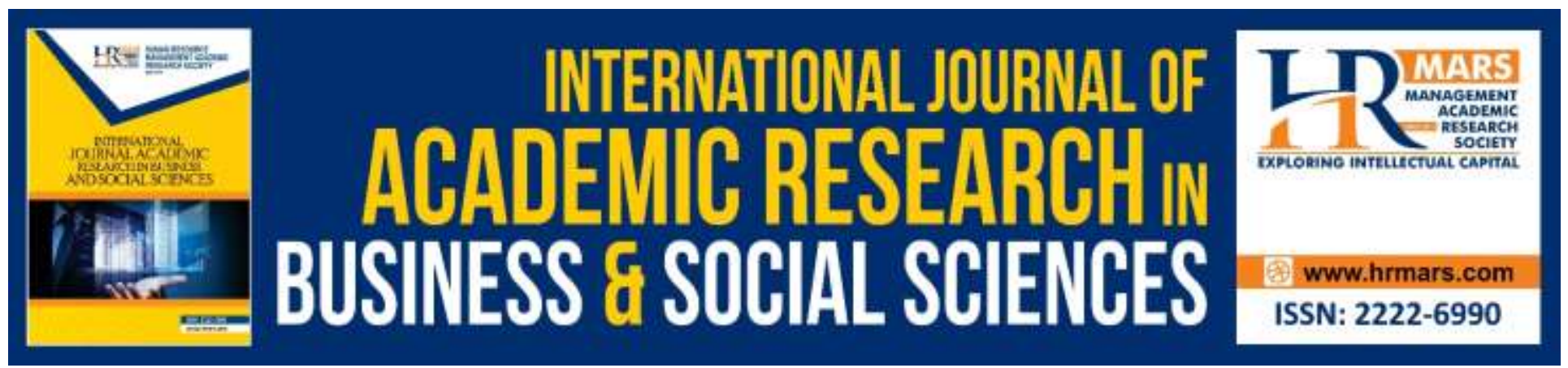

\title{
Exploring the Listening Skills among the Engineering and Non-Engineering Undergraduates
}

\author{
Lee MingFoong, Fazlinda Ab Halim
}

To Link this Article: http://dx.doi.org/10.6007/IJARBSS/v9-i13/6244

DOI: $10.6007 /$ IJARBSS/v9-i13/6244

Received: 20 March 2019, Revised: 18 June 2019, Accepted: 04 July 2019

Published Online: 25 August 2019

In-Text Citation: (MingFoong \& Halim, 2019)

To Cite this Article: MingFoong, L., \& Halim, F. A. (2019). Exploring the Listening Skills among the Engineering and Non-Engineering Undergraduates. International Journal of Academic Research in Business and Social Sciences, 9(13), 77-86.

\section{Copyright: (C) 2019 The Author(s)}

Published by Human Resource Management Academic Research Society (www.hrmars.com)

This article is published under the Creative Commons Attribution (CC BY 4.0) license. Anyone may reproduce, distribute, translate and create derivative works of this article (for both commercial and non-commercial purposes), subject to full attribution to the original publication and authors. The full terms of this license may be seen

at: http://creativecommons.org/licences/by/4.0/legalcode

Special Issue: Revolutionizing Education: Challenges, Innovation, Collaboration, 2019, Pg. 77 - 86

http://hrmars.com/index.php/pages/detail/IJARBSS

JOURNAL HOMEPAGE

Full Terms \& Conditions of access and use can be found at http://hrmars.com/index.php/pages/detail/publication-ethics 


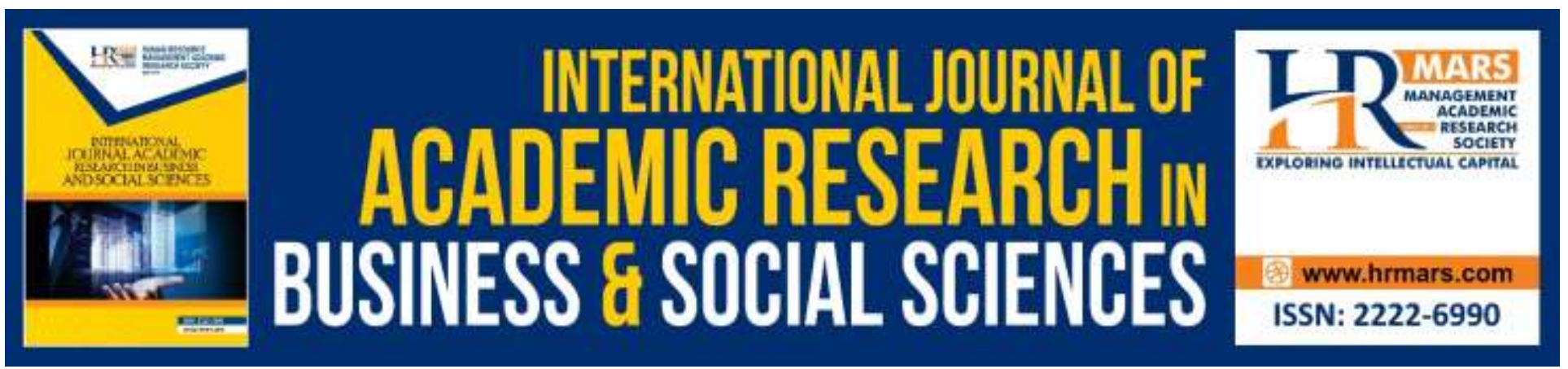

\title{
Exploring the Listening Skills among the Engineering and Non-Engineering Undergraduates
}

\author{
Lee MingFoong, Fazlinda Ab Halim \\ Universiti Tun Hussein Onn Malaysia, Malaysia
}

\begin{abstract}
Listening is an important skill in our daily life, from home to school and at the workplace. Listening skill plays a key role to ensure the effective communication occur between the information deliver and receiver. Furthermore, communication skill is one of the 21 st century skills must be mastered by the students to prepare themselves in facing the challenge at competitive job market. Therefore, a survey using a self-rating test was conducted to determine the listening skills among the undergraduate students in Universiti Tun Hussein Onn Malaysia. A total numbers of 165 students from engineering faculties and non-engineering faculties were strata randomly selected as respondents in this study. The gathered data were analysed using frequency, percentage and independent t-test. The findings showed that majority of the students possess to medium level of listening skills and they need to improve themselves to learn to listen more skilfully especially in difficult situations with others. The findings also showed that there was no significant difference in listening skill level among the students from the aspect of gender and field of study. In summary, higher education institutions are recommended to integrate and expose students effective listening skills in their program or courses and lead them to the success of learning and vital social skills.
\end{abstract}

Keywords: Listening Skills, Undergraduate Students, Engineering, Non-Engineering

\section{Introduction}

Listening is a skill always been neglected in learning even in working. Listening is the ability to accurately receive and interpret messages in the communication process. Indeed, listening play an important role to ensure the effective communication take place. Nowadays, a lot of employers request the listening skills training or courses for their employees as the employer knows that listening is one of the main factors behind the success of the organization. Moreover, good listening skills can lead to greater productivity of an organization by reducing the mistakes and improving the right information sharing that result in most innovative and creative work (SkillsYouNeed, 2018). A research finding by Adler, et.al (2001) in SkillsYouNeed showed that about $45 \%$ of an adult is spent listening during the communication process compared to speaking (30\%), reading (16\%) and writing (9\%). In fact, as a student, he/she can get a lot of benefits by mastering listening skills, such as 
improved communication skills, more time on task, increased academic understanding, enhanced interpersonal connections, and sharpened listening skills (LoBello, 2018). However, for those who are weak in listening, they can learn at any time and improve throughout their lives (Nurn \& Payment, 2000).

According to Abdullah, Zain, Ambotang, Taat and Talip (2011), previous studies showed that students sit in front or near to lecturer tend to improve their listening skills. Besides, the level of concentration and understanding among the students sits in front or near to lecturer able to achieve $61 \%$ compared to those sitting far from the lecturer during the class. Subsequently, concentration, rate will reduce about $5 \%$ to $10 \%$ each row towards the back side of the classroom. Effective listening skills are needed at a higher learning institution because students require listening to a long period of time in the thinking process in order to generate an idea to express their opinions, ideas or what's in mind. Hence, the purpose of this study was conducted to indicate the listening skill level among the undergraduate students, and to identify the difference in listening skill level among the students from the aspects of gender (male and female) and field of study (engineering and non-engineering).

Many articles showed that engineering and non-engineering students tend to have different in many things. As stated by Heather (2007), engineering students tend to get answer for a solution that always has the constant method. This situation may due to the focus of engineering discipline is logical and fact (Lee \& Adam, 2016). On the other hand, non-engineering students always have has a great variety of solution for a single problem with the suitable and acceptable argument (Heather, 2007). This may due to the non-engineering discipline focus on the process of finding answer (Lee \& Adam, 2016). In line with American Society for Engineering Education (2011), the industry always complained that the engineering graduates are poor in communication skills. Furthermore, communication skills is one of the important 21-century skills being hot debate now. Good communication skills always need good listening skills because listening skills is important over other skills (Latha, 2018).

\section{Methodology}

This study adopted a survey method as research design to determine the listening skills level among the engineering and non-engineering undergraduate students. A total numbers of 165 students from eight faculties were involved in this study as sample. The involved faculties were electrical engineering, mechanical engineering, civil engineering, technology engineering, compter science, technology management, sains, and education faculties. They were selected through strata random sampling technique. A self-rating test (Burn \& Payment, 2000) was used as instrument to collect the rating on listening skills from the sample. This test consists of 15 questions from the aspect of effective listening. Samples were required to rate their listening skills using 5 point Likert Scale, with the indicator " $1=$ None of the time; $2=$ Rarely; $3=$ About half of the time; $4=$ Most off the time; $5=$ All the time". The total score of the samples were obtained to identify their listening skills level and the interpretation of the scores are as follow:

60-75: Excellent listening skills during the difficult situation you encountered. Do well most of the time and friends believe that you are good listener. 
45-59: $\quad$ Need to learn to listen more skilfully, in difficult situations with others. Must start to improving skills.

Less than 45: Other people did not believe you were listening. Must start to focus the weak areas.

Furthermore, Alpha Cronbach was used to ensure the reliability of the test. The finding of the pilot test showed that the $\alpha$ value $=.788$. Thus, this test is reliable and suitable to use as an instrument for this study. The gathered data were analyzed using frequency, percentage and independent t-test. Frequency and percentage were used to determine the listening skill level among the undergraduate students, meanwhile the independent t-test was used to identify the difference in listening skill level among the students from the aspects of gender (male and female) and field of study (engineering and non-engineering).

\section{Results and Discussion}

\section{Listening Skills Level among the Undergraduate Students}

Table 1 illustrates the level of effective listening skills among the undergraduate students in general. The majority of the students tend to have middle level of listening skills, about $66 \%$ of them need to learn to listen more skilfully. This situation is matched with the claims of the employers saying that the graduates are lacking in communication skills. In line with the statement mention by SkillsYouNeed (2018), listening is the ability to accurately receive and interpret messages in the communication process because listening is not equal to hearing as listening require focus and concentrated effort. Finding showed a worried situation as about $8 \%$ of the undergraduate students weak in listening skills, they fail to convince people to believe there were listening. Table 2 shows the effective listening skills for 15 aspects. The majority of the students tend to have high scores in "maintained appropriate voice control" with mean $=4.02, \mathrm{SD}=.788$. On the other hand, most of them are weak in "did not talk while the other person was speaking" with mean = 3.32, SD =. 974 . This finding showed that undergraduates tend to interrupt other people when the other person was speaking.

Table 1. Level of Effective Listening Skills among the Undergraduate Students

\begin{tabular}{|c|c|c|}
\hline Effective Listening Skills & Frequency & Percentage \\
\hline Excellent listening skills & 43 & 26.1 \\
\hline Need to learn to listen more skilfully & 109 & 66.0 \\
\hline $\begin{array}{l}\text { Other people did not believe you were } \\
\text { listening }\end{array}$ & 13 & 7.9 \\
\hline Total & 165 & 100.0 \\
\hline
\end{tabular}


INTERNATIONAL JOURNAL OF ACADEMIC RESEARCH IN BUSINESS AND SOCIAL SCIENCES

Vol. 9, No. 13, Special Issue: Revolutionizing Education: Challenges, Innovation, Collaboration., 2019, E-ISSN: 2222-6990 @ 2019 HRMARS

Table 2. Mean Score and Standard Deviation of Effective Listening Skills

\begin{tabular}{llll}
\hline Item & Effective Listening Skills & $m$ & $S D$ \\
\hline 1 & I faced the person through the conversation. & 3.77 & .992 \\
2 & I did not interrupt. & 3.47 & .954 \\
3 & I did not talk while the other person was speaking. & 3.32 & .974 \\
4 & I listened for main ideas and concepts. & 3.44 & .983 \\
5 & I listened for vocal tones. & 3.47 & .979 \\
6 & I observed body language. & 3.87 & .905 \\
7 & I kept an open mind. & 3.97 & .879 \\
8 & I did not use the person's pauses as my signal to begin speaking. & 3.42 & .905 \\
9 & I used appropriate listening responses such as “I see". & 3.43 & 1.138 \\
10 & I asked questions to clarify the speaker's meaning. & 3.87 & .849 \\
11 & I did not plan what I was going to say while the person was & 3.44 & .879 \\
& speaking. & & \\
12 & I maintained appropriate body language. & 3.65 & .916 \\
13 & I maintained appropriate facial expressions. & 3.80 & .857 \\
14 & I maintained appropriate voice control. & 4.02 & .788 \\
15 & I did not use fake smiles. & 3.88 & .968 \\
\hline
\end{tabular}

$m$ mean, $S D$ standard deviation

Table 3 shows the level of effective listening skills between the male and female undergraduate. People always believe that female tend to be a good listener compare to male due to the nature of gender. About 30\% female undergraduate fell into category of excellent listening skills during the difficult situation they encountered compare to male undergraduate that only $22.2 \%$. Both male and female undergraduates were good in "maintained appropriate voice control", for male mean $=4.07$ and SD $=.76$ while for female mean $=3.98$ and $S D=.82$ as stated in Table 4. However, as illustrated in Figure 1, both male and female undergraduates tend to have a similar achievement for 15 aspects in effective listening skills.

Table 3. Level of Effective Listening Skills between Male and Female Students

\begin{tabular}{lllll}
\hline & & \multicolumn{3}{l}{ Gender } \\
\cline { 3 - 4 } Score & & Male & Female & Total \\
\hline$<45 \%$ & Frequency & 6 & 7 & 13 \\
& \% within gender & $7.4 \%$ & $8.3 \%$ & $7.9 \%$ \\
$45-59 \%$ & Frequency & 57 & 52 & 109 \\
& \% within gender & $70.4 \%$ & $61.9 \%$ & $66.1 \%$ \\
$60-75 \%$ & Frequency & 18 & 25 & 43 \\
& \% within gender & $22.2 \%$ & $29.8 \%$ & $26.1 \%$ \\
\hline Total & Frequency & 81 & 84 & 165 \\
& \% within gender & $100.0 \%$ & $100.0 \%$ & $100.0 \%$ \\
\hline
\end{tabular}


INTERNATIONAL JOURNAL OF ACADEMIC RESEARCH IN BUSINESS AND SOCIAL SCIENCES

Vol. 9, No. 13, Special Issue: Revolutionizing Education: Challenges, Innovation, Collaboration., 2019, E-ISSN: 2222-6990 @ 2019 HRMARS

Table 4. Mean Score and Standard Deviation of Effective Listening Skills between Male and Female Undergraduate Students

\begin{tabular}{llllll}
\hline \multirow{2}{*}{ Item } & \multirow{2}{*}{ Effective Listening Skills } & \multicolumn{3}{l}{ Male } & \multicolumn{3}{l}{ Female } \\
\cline { 3 - 6 } & & $m$ & $S D$ & $m$ & \multicolumn{1}{l}{$S D$} \\
\hline 1 & I faced the person through the conversation. & 3.75 & .90 & 3.79 & 1.08 \\
2 & I did not interrupt. & 3.52 & .95 & 3.43 & .96 \\
3 & I did not talk while the other person was speaking. & 3.27 & .91 & 3.36 & 1.04 \\
4 & I listened for main ideas and concepts. & 3.44 & .95 & 3.43 & 1.02 \\
5 & I listened for vocal tones. & 3.41 & 1.01 & 3.52 & .95 \\
6 & I observed body language. & 3.90 & .90 & 3.85 & .91 \\
7 & I kept an open mind. & 3.96 & .90 & 3.97 & .86 \\
8 & I did not use the person's pauses as my signal to begin & 3.37 & .94 & 3.48 & .87 \\
& speaking. & & & & \\
9 & I used appropriate listening responses such as “I see". & 3.26 & 1.15 & 3.60 & 1.11 \\
10 & I asked questions to clarify the speaker's meaning. & 3.88 & .91 & 3.87 & .79 \\
11 & I did not plan what I was going to say while the person & 3.40 & .90 & 3.49 & .86 \\
& was speaking. & & & & \\
12 & I maintained appropriate body language. & 3.59 & .97 & 3.70 & .86 \\
13 & I maintained appropriate facial expressions. & 3.69 & .92 & 3.90 & .79 \\
14 & I maintained appropriate voice control. & 4.07 & .76 & 3.98 & .82 \\
15 & I did not use fake smiles. & 3.80 & .90 & 3.95 & 1.03 \\
\hline
\end{tabular}

$m$ mean, $S D$ standard deviation

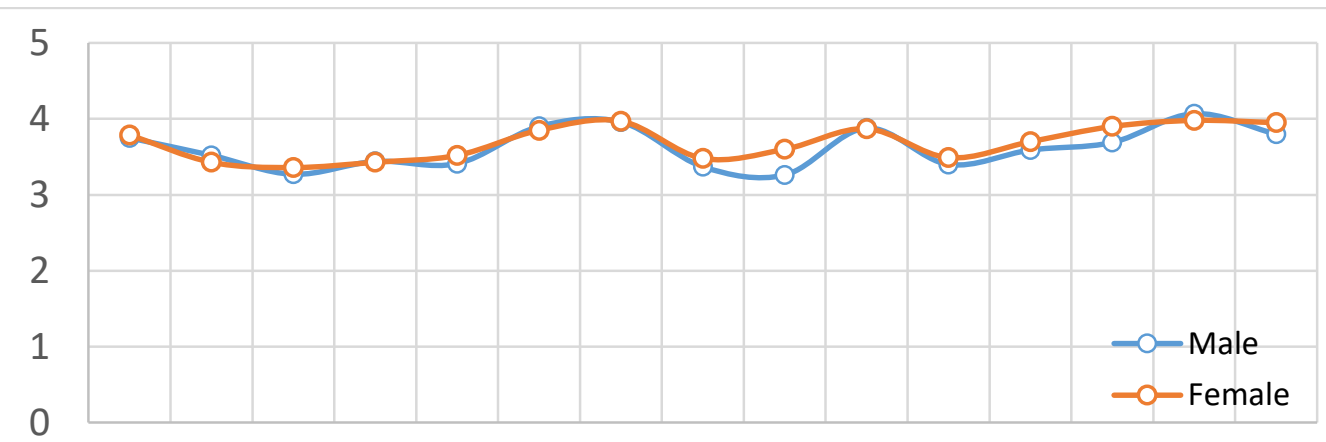

item item item item item item item item item item item item item item item $\begin{array}{lllllllllllllll}1 & 2 & 3 & 4 & 5 & 6 & 7 & 8 & 9 & 10 & 11 & 12 & 13 & 14 & 15\end{array}$

Figure 1. Graph for Effective Listening Skills Score between Male \& Female Undergraduate Students

Table 5 shows the level of effective listening skills between the Engineering and Non-Engineering undergraduate. Most of the people will think that non-engineering students are learning social science and they tend to be a talkative person than engineering students that only knowing things in straight forward. Surprisingly, the finding showed that about $28.7 \%$ engineering undergraduate fell into category of excellent listening skills during the difficult situation they encountered compare to non-engineering undergraduate that only $23.1 \%$. Engineering undergraduates tend to have high 
INTERNATIONAL JOURNAL OF ACADEMIC RESEARCH IN BUSINESS AND SOCIAL SCIENCES

Vol. 9, No. 13, Special Issue: Revolutionizing Education: Challenges, Innovation, Collaboration., 2019, E-ISSN: 2222-6990 @ 2019 HRMARS

scores in "I observed body language" with mean $=4.01$ and SD $=.93$. On the other hand, nonengineering undergraduates tend to have high scores in "I maintained appropriate voice control" with mean $=4.06$ and SD =.71 as stated in Table 6. However, as illustrated in Figure 2, both engineering and non-engineering undergraduates tend to have a similar achievement for 15 aspects in effective listening skills.

Table 5. Level of Effective Listening Skills between Engineering and Non-Engineering Students

\begin{tabular}{lllll}
\hline & & \multicolumn{2}{l}{ Field of Study } & \\
\cline { 3 - 4 } Score & & Engineering & Non-Engineering & Total \\
\hline$<45 \%$ & Frequency & 9 & 4 & 13 \\
& \% within gender & $10.3 \%$ & $5.1 \%$ & $7.9 \%$ \\
$45-59 \%$ & Frequency & 53 & 56 & 109 \\
& \% within gender & $60.9 \%$ & $71.8 \%$ & $66.1 \%$ \\
$60-75 \%$ & Frequency & 25 & 18 & 43 \\
& \% within gender & $28.7 \%$ & $23.1 \%$ & $26.1 \%$ \\
\hline Total & Frequency & 87 & 78 & 165 \\
& \% within gender & $100.0 \%$ & $100.0 \%$ & $100.0 \%$ \\
\hline
\end{tabular}

Table 6. Mean Score and Standard Deviation of Effective Listening Skills between Engineering and Non-Engineering Undergraduate Students

\begin{tabular}{|c|c|c|c|c|c|}
\hline \multirow[t]{2}{*}{ Item } & \multirow{2}{*}{ Effective Listening Skills } & \multicolumn{2}{|c|}{ Engineering } & \multicolumn{2}{|c|}{$\begin{array}{l}\text { Non- } \\
\text { Engineering }\end{array}$} \\
\hline & & $m$ & $S D$ & $m$ & $S D$ \\
\hline 1 & I faced the person through the conversation. & 3.75 & 1.12 & 3.79 & .83 \\
\hline 2 & I did not interrupt. & 3.46 & 1.05 & 3.49 & .83 \\
\hline 3 & I did not talk while the other person was speaking. & 3.41 & 1.04 & 3.21 & .89 \\
\hline 4 & I listened for main ideas and concepts. & 3.44 & 1.06 & 3.44 & .89 \\
\hline 5 & I listened for vocal tones. & 3.55 & 1.10 & 3.37 & .82 \\
\hline 6 & I observed body language. & 4.01 & .93 & 3.72 & .85 \\
\hline 7 & I kept an open mind. & 4.00 & .99 & 3.94 & .83 \\
\hline 8 & $\begin{array}{l}\text { I did not use the person's pauses as my signal to } \\
\text { begin speaking. }\end{array}$ & 3.39 & .99 & 3.46 & .80 \\
\hline 9 & $\begin{array}{l}\text { I used appropriate listening responses such as "I } \\
\text { see". }\end{array}$ & 3.41 & 1.19 & 3.45 & 1.09 \\
\hline 10 & I asked questions to clarify the speaker's meaning. & 3.90 & .95 & 3.85 & .72 \\
\hline 11 & $\begin{array}{l}\text { I did not plan what I was going to say while the } \\
\text { person was speaking. }\end{array}$ & 3.30 & .90 & 3.60 & .83 \\
\hline 12 & I maintained appropriate body language. & 3.77 & .99 & 3.51 & .83 \\
\hline 13 & I maintained appropriate facial expressions. & 3.86 & .90 & 3.73 & .80 \\
\hline 14 & I maintained appropriate voice control. & 3.99 & .86 & 4.06 & .71 \\
\hline 15 & I did not use fake smiles. & 3.83 & .96 & 3.94 & .97 \\
\hline
\end{tabular}

$m$ mean, $S D$ standard deviation 
INTERNATIONAL JOURNAL OF ACADEMIC RESEARCH IN BUSINESS AND SOCIAL SCIENCES

Vol. 9, No. 13, Special Issue: Revolutionizing Education: Challenges, Innovation, Collaboration., 2019, E-ISSN: 2222-6990 @ 2019 HRMARS

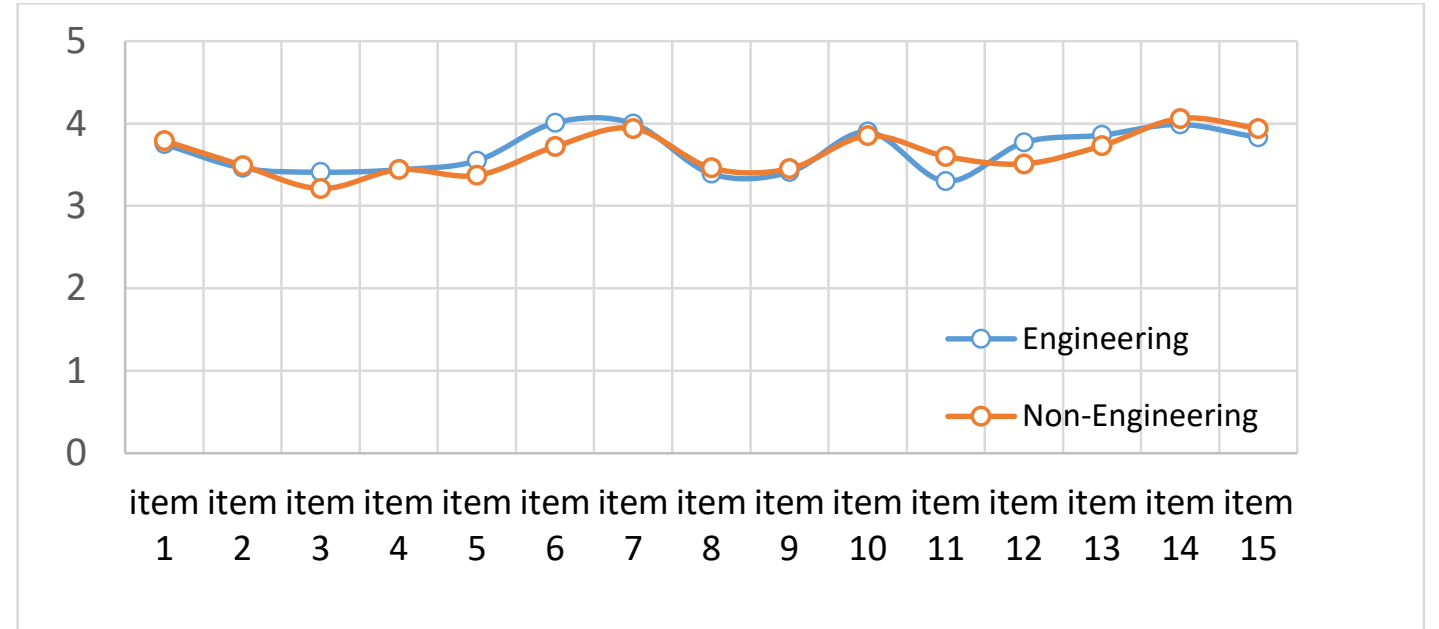

Figure 2. Mean Score Graph for Effective Listening Skills between Engineering and Non-Engineering Undergraduate Students

\section{Difference in Listening Skills Level between Male and Female Students}

Table 7 shows that female students tend to have higher score in listening skills than male students with mean difference $=.988$. However, independent t-test in Table 8 shows that there is no significant difference in listening skills between male and female students, $t(163)=-.902, p=.368$. Therefore, lecturers may teach students, regardless the gender issue. Students should develop adequate listening skills in the classroom no matter how intelligent he/she is to lead them reap the benefits of his/her education because students need to listen keenly to the directions and lectures rather than simply hearing them (LoBello, 2018). In addition, about $60 \%$ of the time spent by students is used for the listening purpose (Abdullah, Zain, Ambotang, Taat \& Talip, 2011).

Table 7. Group Statatistics of Effective Listening Skills between Male and Female Undergraduate

\begin{tabular}{llll} 
& \multicolumn{3}{c}{ Students } \\
\hline Gender & $\mathrm{N}$ & Mean & Std. Deviation \\
\hline Male & 81 & 54.32 & 6.33 \\
Female & 84 & 55.31 & 7.66 \\
\hline
\end{tabular}

Table 8. Independent Samples Test of Effective Listening Skills between Male and Female Undergraduate Students

\begin{tabular}{llll}
\hline$t$ & $d f$ & Sig. (2-tailed) & Mean Difference \\
\hline-.902 & 163 & .368 & .98854 \\
\hline
\end{tabular}




\section{Difference in Listening Skills Level between Engineering and Non-Engineering Students}

Table 9 shows that non-engineering students tend to have higher score in listening skills than engineering students with mean difference $=.518$. However, independent t-test in Table 10 shows that there is no significant difference in listening skills between engineering and non-engineering students, $\mathrm{t}(163)=.471, \mathrm{p}=.638$. According to Abdullah, Zain, Ambotang, that \& Talip (2011), university students tend to spend $50 \%$ to $100 \%$ of their time in listening during the lecturing. Since there is no significant difference in listening skills between engineering and non-engineering students, lecturers should deliver their regardless to the field of study of the students. Research finding showed that students tend to spend much of their time listening than speaking, reading and writing, however, only $25 \%$ of a brief discussion will be retained after a few days (ACS, 2011). Thus, the lecturer is suggested to train the students to be an active listener than a hearing during the learning process occur.

Table 9. Group Statistics of Effective Listening Skills between Engineering and Non-Engineering Undergraduate Students

\begin{tabular}{llll}
\hline Field of Study & $\mathrm{N}$ & Mean & Std. Deviation \\
\hline Engineering & 81 & 54.55 & 5.98 \\
Non- & 84 & 55.07 & 7.89 \\
Engineering & & & \\
\hline
\end{tabular}

Table 10. Independent Samples Test of Effective Listening Skills between Engineering and NonEngineering Undergraduate Students

\begin{tabular}{llll}
\hline $\mathrm{t}$ & $\mathrm{df}$ & Sig. (2-tailed) & Mean Difference \\
\hline .471 & 163 & .638 & .518 \\
\hline
\end{tabular}

\section{Conclusion}

The finding in this study showed that undergraduate students tend to have the middle score in listening skills. Finding also indicated that there is no significant difference in listening skill level among the undergraduate students from the aspect of gender and field of study. Either students or lecturers must master the listening skills to ensure the meaning learning process occur because listening is the key to all effective communication (SkillsYouNeed, 2018). Without an effective communication during the learning process, both lecturer and student can be easily become frustrated and irritated. As mentioned earlier in this article, listening skills can be learned and be improved. Consequently, lecturer or student is encouraged to learn listening skills effectively, for example, a HURIER model of listing that developed by Judi Brownell from Cornell University (SkillsYouNeeds, 2018) that emphasize on key components of active listening. Further study is recommended to focus on method enhancing students listening skills and the impact of active listening skills towards the undergraduate employability rate.

\section{Acknowledgements}

The publication of this work was supported by the PPG grant (Vote No.V012) awarded by ministry of Education Malaysia (MOE) and the Research \& Management Centre (RMC) of Universiti Tun Hussein 
Onn Malaysia (UTHM). The authors would like to thank to all BBD30402 course students, Faculty of Technical \& Vocational Education (FPTV), UTHM, enrolled in semester 1 session 2016/2017, for their support in data collection and analyses for this study. The authors would also like to thanks to those who graciously gave their time to participate in this study.

\section{References}

Abudllah, M. Y., Zain, S., Ambotang, A. S., Taat, M. S. \& Talip, R. (2011, Nov 9). Mendengar aspek yang sering terabai. Utusan, p.B4. Available at http://eprints.ums.edu.my/696/1/nc0000000881.pdf

ACS. EDU. AU. (2011). Listening skills for teachers, how to listen, how to communicate. Available at https://www.acs.edu.au/info/education/trends-opinions/listening-skills.aspx. Accessed 7 Nov 2018.

American Society for Engineering Education. (2011). Why Industry Says That Engineering Graduates Have Poor Communication Skills: What the Literature Says. Availed at https://www.asee.org/public/conferences/1/papers/1503/download

Burn, B. \& Payment, M. (2000). Assessments A to Z. San Francisco: Jossey-Bass.

Heather, N. (2007). Overcoming Depression: The University of Nottingham. Dicapai pada November 9, 2014, pp. 32 di http://www.nottingham.acuk/counseling/leaflets/ depression.pdf

Lee, M. F. \& Wan Adam. W. M. H. (2016). A Comparison Study of Methods to Solve The Mental Health Problem Between The Engineering And Non-Engineering Students. IEEE International Conference on Industrial Engineering and Engineering Management, Volume 2016-December, 27 December 2016, Pages 179-183.

LoBello, K. (2018). What are the benefits off listening in the classroom? https://www.theclassroom.com/benefits-listening-classroom-8611009.html. Accessed 7 Nov 2018.

Latha, M. A. (2018). Importance of Listening Skills over Other Skills. International Journal of Advance Engineering and Research Development (IJAERD) International Conference of Trends in Information, Management, Engineering and Sciences (ICTIMES) Volume 5, Special Issue 02, Feb.2018

SkillsYouNeed. (2018). Listening Skills. https://www.skillsyouneeded.com/ips/listening-skills.html. Accessed 7 Nov 2018. 